\title{
Influence of edaphic factors on the floristic composition of an area of cerradão in the Brazilian central-west
}

Marcelo Leandro Bueno ${ }^{1,5}$, Danilo Rafael Mesquita Neves ${ }^{1}$, Anderson Fernandes Souza ${ }^{2}$, Elio Oliveira Junior ${ }^{3}$, Geraldo Alves Damasceno Junior ${ }^{3}$, Vanessa Pontara ${ }^{1}$, Valdemir Antônio Laura ${ }^{3}$ and James Alexander Ratter ${ }^{4}$

Submitted: 30 March, 2012. Accepted: 16 April, 2013

\begin{abstract}
This study describes the influence of edaphic factors on the floristic composition of an area of cerradão (woodland savanna) in the city of Campo Grande, located in the Brazilian central-west. In 10 plots $(5 \times 20 \mathrm{~m}$ each), we evaluated all trees with a diameter at breast height $\geq 4.77 \mathrm{~cm}$. Soil samples were analyzed for each plot in order to determine edaphic variables correlated with species composition. We sampled 1180 individuals of 61 species. The evenness index was 0.74 , which indicates uneven distribution of species, which was explained by a high abundance of Qualea parviflora, Curatella americana, Qualea grandiflora, Terminalia argentea and Astronium fraxinifolium. We registered more trees in the smallest diameter class and in the middle layer of the vertical structure. The soil was dystrophic with a clay texture, which explains the higher abundance of species related to dystrophic cerradão. However, we also found some trees typical of mesotrophic cerradão and deciduous forests, which could be attributable to the presence of patches of fertile soil within the dystrophic cerradão or could indicate that those mesotrophic species are tolerant of lower levels of soil nutrients.
\end{abstract}

Key words: cerrado, dystrophic cerradão, mesotrophic cerradão, phytosociology, soil-plant interaction

\section{Introduction}

The Cerrado biome of Brazil possesses physiognomies that comprise grassland, savanna and forest formations. Edaphic factors such as effective depth, presence of concretions in the soil profile, proximity of the water table to the surface, drainage, and fertility are among the most important determinants of the floristic composition, structure and productivity of the native vegetation (Haridasan 2000).

Of the forest formations, the woodland known as the cerradão is distinct because of its low height and xeromorphic features, corresponding to a "mesophilous sclerophyllous forest", with trees of 8-15 m, understory composed of shrubs and treelets that can reach $3 \mathrm{~m}$, and a sparse herbaceous layer with low species richness. The cerradão contains species that co-occur in the cerrado típico (a savanna formation that constitutes the most widespread physiognomy of the cerrado biome) and in several other types of forests (Ribeiro \& Walter 2008).

Haridasan (1992) argued that factors such as water availability in the soil and soil composition might play a role in phytophysiognomic differentiation, providing higher nutrient availability, thus enabling the establishment of vegetation with greater density and height, as in the case of the cerradão. The author also argued that such physiognomy could remain in dystrophic soils because of the closed nutrient cycle.

Two types of cerradão with floristic and soil differences have been described, one characteristics of mesotrophic soils with higher $\mathrm{pH}$ and levels of $\mathrm{Ca}$ and $\mathrm{Mg}$ and the other of dystrophic soils of lower $\mathrm{pH}, \mathrm{Ca}$ and $\mathrm{Mg}$ (Ratter 1971, Ratter et al. 1973, 1977, 1996, 2003, 2006, 2011; Furley \& Ratter 1988). In the earlier publications of the series these communities were named after characteristics marker tree species: Hirtella glandulosa Spreng and Emotum nitens (Benth.) Miers for dystrophic and Magonia pubescens St. Hill., and Callisthene fasciculata (Spreng) for mesotrophic, but later the terms "dystrophic cerradão" and mesotrophic cerradão" were used. The soils of dystrophic cerradão show $\mathrm{pH}$ and minerals similar to these open forms of cerrado, but higher clay content, indicating greater retention of water in cases that have been analyzed (Assis et al. 2011).

\footnotetext{
${ }^{1}$ Universidade Federal de Minas Gerais, Departamento de Botânica, Programa de Pós-Graduação em Biologia Vegetal, Belo Horizonte, MG, Brazil

${ }^{2}$ Universidade Estadual do Norte Fluminense Darcy Ribeiro, Departamento de Genética e Melhoramento, Campos dos Goytacazes, RJ, Brazil

${ }^{3}$ Universidade Federal de Mato Grosso do Sul, Departamento de Biologia, Programa da Pós-Graduação em Biologia Vegetal, Campo Grande, MS, Brazil

${ }^{4}$ Royal Botanic Garden Edinburgh, Scotland, UK

${ }^{5}$ Author for correspondence: buenotanica@gmail.com
} 
In keeping with the observations of many of the previously cited authors, Assis et al. (2011) found no correlation between soil fertility and cerradão. However, those authors described the considerable correlation that dystrophic cerradão displays with high levels of clay and microporosity, resulting in greater water retention, thus enabling the occurrence of a more exuberant vegetation (i.e., cerradão). Therefore, considering the latest discussions on this subject, it seems that soil texture determines the vegetation structure, whereas soil fertility determines the floristic type of cerradão (Ratter 1971; Ratter et al. 1973, 1977; Furley \& Ratter 1988).

Because studies of soil-plant interaction are useful tools to improve the understanding of the floristic patterns of the cerrado biome and to aid in its preservation, in this study, we evaluated the relationship between floristic composition and edaphic variables in the cerradão in the municipality of Campo Grande, in the state of Mato Grosso do Sul. We hypothesized that the distribution and dominance of species in the cerradão are related to chemical and physical attributes of the soil.

\section{Material and methods}

\section{Study site}

The study was conducted in an urban cerrado fragment of 36.5 hectares, located within the Reserva Particular do Patrimônio Natural (RPPN, Private Nature Reserve) operated by the Universidade Federal de Mato Grosso do Sul (UFMS, Federal University of Mato Grosso do Sul), in the munici-

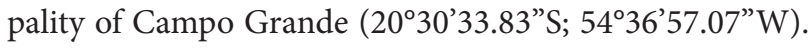
According to the Köppen climate classification system (Köppen 1948), the climate is type Aw (rainy tropical savanna), characterized by a dry period during winter and a rainy period during summer, with an average annual precipitation of 1,532 mm (Embrapa 1985). According to the Brazilian Agency for Agricultural Research (Embrapa 2006), the predominant soil types in the region are dystroferric red latosol and udorthent.

\section{General aspects of the vegetation}

Using the phytophysiognomic classification of the cerrado biome proposed by Ribeiro \& Walter (2008) as a reference, we identified the following formations in the RPPN of the UFMS: cerrado típico, gallery forest and cerradão.

\section{Sampling}

We used the plot method (Mueller-Dombois \& Ellenberg 1974). The survey was conducted in one hectare, in ten 50 $\times 20 \mathrm{~m}$ plots, randomly distributed. We included all living woody individuals with a diameter at breast height $(\mathrm{DBH})$ $\geq 4.77 \mathrm{~cm}$. The total height of trees was estimated visu- ally, using a $5 \mathrm{~m}$ graduated measuring stick. All botanical material was preserved and later deposited in the Campo Grande-Mato Grosso do Sul Herbarium (code, CGMS). We identified specimens by consulting the literature, by comparing them with specimens deposited in the CGMS Herbarium or by enlisting the aid of specialists. The plant families were listed according to the Angiosperm Phylogeny Group III guidelines (APG III 2009).

\section{Soil collection}

The collection of soils for the analysis of fertility was carried out with a probe type auger. In each plot, we collected a sample comprising 20 subsamples, randomly collected at depths of $0 \mathrm{~cm}$ to $20 \mathrm{~cm}$. The chemical and physical analyses were conducted in the Soil Fertility Laboratory of the Anhanguera University for the Development of the Pantanal Region, following the methodology described by the Brazilian Agency for Agricultural Research (Embrapa 1998).

\section{Data analysis}

We analyzed the following phytosociological parameters (Mueller-Dombois \& Ellenberg 1974): basal area, absolute density, relative density, absolute frequency, relative frequency, absolute dominance, relative dominance, cover value, and importance value (IV). We evaluated floristic diversity by calculating the Shannon index $\left(\mathrm{H}^{\prime}\right)$ and Pielou's evenness index ( $\left.J^{\prime}\right)$, as described by Brower \& Zar (1984). All parameters were estimated with the software Mata Nativa 2 (Cientec 2007).

For the analysis of diametric classes, the individuals were distributed in diameter classes with the ideal class interval (CI=7.1) calculated according to the formulae put forth by Spiegel (1976):

$$
\begin{gathered}
C I=A / N C \\
N C=1+3.3 \log N
\end{gathered}
$$

where $\mathrm{A}$ is the amplitude of diameters, $\mathrm{NC}$ is the number of classes, and $\mathrm{N}$ is the number of individuals.

Although there are several criteria for height stratification to estimate the absolute sociological position per species in the plant community, we used three height layers, following the recommendation of Paula et al. (2004). A posteriori, we applied the D'Agostino-Pearson normality test, according to Zar (1999).

To establish the relationships between plots/species and soil parameters, we performed canonical correspondence analysis (CCA), as described by ter Braak (1988). The CCA requires two matrices, one with the species per plot data and another with the explanatory variables. The highest correlations were found for the following variables: texture (clay), organic matter, phosphorus, potassium, aluminium 
saturation, base saturation, sum of bases, cation exchange capacity (CEC) and $\mathrm{pH}$.

There are several advantages in the use of the CCA, the greatest of which is the Monte Carlo test, which consists in randomly permuting the lines of the matrix of environmental variables to test the significance of the correlation between the two matrices, identifying the probability that the relationship observed between the two original matrices is correct. The CCA and the Monte Carlo test were processed by the program PC-ORD for Windows, version 5.0 (McCune \& Mefford 2006).

\section{Results and discussion}

\section{Floristics and structure}

We recorded 61 species, belonging to 52 genera, distributed in 31 families (Tab. 1). Of the sampled families, Fabaceae had the highest richness, with 11 species; followed by Vochysiaceae (6 species); Erythroxylaceae (4 species); Annonaceae, Anacardiaceae, and Myrtaceae (3 species each); and Bignoniaceae, Chrysobalanaceae, Combretaceae, Connaraceae, Malpighiaceae, and Malvaceae (2 species each). These families accounted for $68.85 \%$ of the species observed at the study site. The remaining 19 families were represented by only one species each.

The most prominent families in this study were the same families found in other cerradão areas (Batalha \& Mantovani 2001; Salis et al. 2006; Silva et al. 2008; Souza et al. 2008; Araújo et al. 2011), especially Fabaceae and Vochysiaceae in areas of dystrophic cerradão (Costa \& Araújo, 2001; Marimon Júnior \& Haridasan, 2005; Araújo et al. 2011).

The H' value obtained (3.03) was similar to those reported for other areas of cerradão in the state of Mato Grosso do Sul, which have ranged from 2.90 to 3.36 (Salis et al. 2006), and lower than those reported for areas of cerradão in the southeast (range, 3.38-3.54; Gomes et al. 2004; Guimarães et al. 2001), northeast (range, 3.31-3.32; Silva et al. 2008; Alencar et al. 2007) and central-west (range, 3.42-3.84; Andrade et al. 2002; Felfili \& Silva Junior 1992; Marimon Junior \& Haridasan 2005). The J' value obtained (0.74) indicated an unequal distribution of individuals per species. The high abundance of five species, Qualea parviflora Mart., Curatella americana L. Qualea grandiflora Mart., Terminalia argentea Mart. and Anadenanthera peregrina var. falcata (Benth.) Altschul, collectively accounting for $55.71 \%$ of the relative density, contributed to the low evenness observed.

The variation in richness and diversity might be related to factors such as the inclusion criterion for trees, basal area, sample size (Pinheiro \& Durigan 2012), soil (Assis et al. 2011; Neri et al. 2013) and biogeography (Ratter et al. 1997). The cerrado areas in the Alto Araguaia region in the state of Mato Grosso, the state of Tocantins and the Federal District have a high species richness in comparison to the marginal and disjunct areas of the cerrado biome (Ratter et al. 1997). However, in marginal areas, floristic elements from adjacent plant formations occur, adding to the richness of the cerrado (Ratter et al. 2003).

Regarding the vertical structure (Fig. 1), 60.25\% of individuals belonged to the middle layer (height, 4.01$7.88 \mathrm{~m}), 21.69 \%$ belonged to the lower layer $(0-4 \mathrm{~m})$, and $18.13 \%$ belonged to the upper layer (7.89-12 $\mathrm{m})$. According to Ratter (1986), the tallest species in the cerradão usually reach 10-12 m, although taller individuals can occur. In the present study, the tallest species were Andira cuyabensis Benth., Bowdichia virgilioides Kunth, Callisthene minor Mart., Curatella americana, Hymenaea stigonocarpa Mart. ex Hayne, Lafoensia pacari A. St.-Hil., Luehea paniculata Mart., Qualea parviflora, Matayba guianensis Aubl., Stryphnodendron obovatum Benth., Tachigali aurea Tul., and Terminalia argentea, with individuals between 10 and $12 \mathrm{~m}$ tall. Of the 61 species recorded, 30 had no individuals in the lower layer, suggesting the existence of restrictions to the natural processes of reproduction, dispersal and regeneration (Silva \& Soares 1999; Toppa 2004). An important factor that might be related to this condition is the human impact on the areas surrounding the study site. This impact causes the isolation of the area, restricting the flux of pollinators, and is a major negative factor in the regeneration process, considering that most tree species depend on animals for their pollination and dispersal (Reis et al. 1999).

The analysis of diametric distribution revealed that most of the individuals belong to the smallest size classes $(71.86 \%$ for the first two classes) (Fig. 2), and that this community has an inverted "J" pattern, which indicates the regenerative capacity of the community. According to Silva Júnior \& Silva (1988), the concentration of individuals in the first two diameter classes might indicate possible past disturbances, natural or anthropic, such as timber harvesting, selective logging, fires, deforestation and herbivory, and might also be explained by the genetic potential of most cerrado species for small size.

The absolute density in the cerradão was 1,180 ind.ha ${ }^{-1}$. This result was lower than that observed for other areas of dystrophic cerradão, such as those in the municipality of Uberlândia, in the state of Minas Gerais (Costa \& Araújo 2001), with 2,071 ind.ha ${ }^{-1}$; in the state of Mato Grosso, with 1,884 ind.ha $^{-1}$ (Marimon Junior \& Haridasan 2005); and in the Federal District, with 2,231 ind.ha ${ }^{-1}$ (Ribeiro et al. 1985). This difference demonstrates the effect of dominant species on the structure, considering that the 10 species with the largest IV accounted for $59.11 \%$ of the total density value and covered $74.51 \%$ of the basal area (Tab. 2). Such numbers might indicate the presence of a restricted group of species with competitive advantages, high DBH and large number of individuals, thus affecting the previously discussed values of density, diversity and evenness.

The fact that the highest IV was obtained for Qualea parviflora corroborates the patterns reported by Ratter et al. (2003), in which Q. parviflora had the second highest 
Marcelo Leandro Bueno, Danilo Rafael Mesquita Neves, Anderson Fernandes Souza, Elio Oliveira Junior, Geraldo Alves Damasceno Junior, Vanessa Pontara, Valdemir Antônio Laura and James Alexander Ratter

Table 1. List of the species recorded in the cerradão of the Private Nature Reserve operated by the Federal University of Mato Grosso do Sul, in the city of Campo Grande, Brazil.

\begin{tabular}{|c|c|c|}
\hline Family & Scientific name & Herbarium record \\
\hline \multirow{3}{*}{ Anacardiaceae } & Astronium fraxinifolium Schott & 24898 \\
\hline & Myracrodruon urundeuva Allemão & 24897 \\
\hline & Tapirira guianensis Aubl. & 24894 \\
\hline \multirow{3}{*}{ Annonaceae } & Annona coriacea Mart. & 24932 \\
\hline & Annona crassiflora Mart. & 24931 \\
\hline & Xylopia aromatica (Lam.) Mart. & 24900 \\
\hline Araliaceae & Schefflera morototoni (Aubl.) Maguire, Steyerm. \& Frodin & 24880 \\
\hline Asteraceae & Piptocarpha rotundifolia (Less.) Baker & 24896 \\
\hline \multirow{2}{*}{ Bignoniaceae } & Handroanthus ochraceus (Cham.) Mattos & 24886 \\
\hline & Tabebuia aurea (Manso) Benth. \& Hook. f. ex S. Moore & 24933 \\
\hline Caryocaraceae & Caryocar brasiliense Cambess. & 24934 \\
\hline \multirow{2}{*}{ Chrysobalanaceae } & Hirtella hebeclada Moric. ex DC. & 24890 \\
\hline & Licania humilis Cham. \& Schltdl. & 24891 \\
\hline Clusiaceae & Kielmeyera coriacea Mart. \& Zucc. & 24930 \\
\hline \multirow{2}{*}{ Combretaceae } & Terminalia argentea Mart. & 24879 \\
\hline & Buchenavia tomentosa Eichler & 24927 \\
\hline \multirow{2}{*}{ Connaraceae } & Connarus suberosus Planch. & 24893 \\
\hline & Rourea induta Planch. & 24929 \\
\hline Dilleniaceae & Curatella americana $\mathrm{L}$. & 24926 \\
\hline \multirow{4}{*}{ Erythroxylaceae } & Erythroxylum anguifugum Mart. & 24887 \\
\hline & Erythroxylum deciduum A. St.-Hil. & 24889 \\
\hline & Erythroxylum suberosum A. St.-Hil. & 24888 \\
\hline & Erythroxylum tortuosum Mart. & 24889 \\
\hline \multirow{11}{*}{ Fabaceae } & Anadenanthera peregrina var. falcata (Benth.) Altschul & 24905 \\
\hline & Andira cuyabensis Benth. & 24902 \\
\hline & Bowdichia virgilioides Kunth & 24906 \\
\hline & Copaifera langsdorffii Desf. & 24922 \\
\hline & Dimorphandra mollis Benth. & 24923 \\
\hline & Dipteryx alata Vogel & 24925 \\
\hline & Diptychandra aurantiaca Tul. & 24903 \\
\hline & Hymenaea stigonocarpa Mart. ex Hayne & 24920 \\
\hline & Leptolobium dasycarpum Vogel & 24924 \\
\hline & Stryphnodendron rotundifolium Mart. & 24904 \\
\hline & Tachigali aurea Tul. & 24921 \\
\hline Lauraceae & Ocotea minarum (Nees \& Mart.) Mez & 24881 \\
\hline Lythraceae & Lafoensia pacari A. St.-Hil. & 24917 \\
\hline \multirow{2}{*}{ Malpighiaceae } & Byrsonima coccolobifolia Kunth & 24883 \\
\hline & Byrsonima verbascifolia (L.) DC. & 24882 \\
\hline \multirow{2}{*}{ Malvaceae } & Eriotheca pubescens (Mart. \& Zucc.) Schott \& Endl. & 24877 \\
\hline & Luehea paniculata Mart. \& Zucc. & 24918 \\
\hline \multirow[t]{2}{*}{ Melastomataceae } & Miconia albicans (Sw.) Triana & 24916 \\
\hline & Eugenia aurata O. Berg & 24908 \\
\hline \multirow[t]{2}{*}{ Myrtaceae } & Eugenia egensis DC. & 24909 \\
\hline & Myrcia guianensis (Aubl.) DC. & 24907 \\
\hline
\end{tabular}


Table 1. Continuation.

\begin{tabular}{|c|c|c|}
\hline Family & Scientific name & Herbarium record \\
\hline Nyctaginaceae & Guapira opposita (Vell.) Reitz. & 24892 \\
\hline Opiliaceae & Agonandra brasiliensis Miers ex Benth. \& Hook. f. & 24895 \\
\hline Primulaceae & Myrsine guianensis Aubl. Kuntze & 24919 \\
\hline Proteaceae & Roupala montana Aubl. & 24911 \\
\hline Rubiaceae & Rudgea viburnoides (Cham.) Benth. & 24884 \\
\hline Rutaceae & Zanthoxylum rigidum Humb. \& Bonpl. ex Willd. & 24899 \\
\hline Salicaceae & Casearia sylvestris Sw. & 24912 \\
\hline Sapindaceae & Matayba guianensis Aubl. & 24878 \\
\hline Sapotaceae & Chrysophyllum marginatum (Hook. \& Arn.) Radlk. & 24885 \\
\hline Styracaceae & Styrax ferrugineus Nees \& Mart. & 24915 \\
\hline Verbenaceae & Aegiphila verticilata Vell. & 24901 \\
\hline \multirow{6}{*}{ Vochysiaceae } & Callisthene minor Mart. & 24874 \\
\hline & Qualea grandiflora Mart. & 24910 \\
\hline & Qualea multiflora Mart. & 24913 \\
\hline & Qualea parviflora Mart. & 24914 \\
\hline & Salvertia convallariodora A. St.-Hil. & 24875 \\
\hline & Vochysia thyrsoidea Pohl & 24876 \\
\hline
\end{tabular}

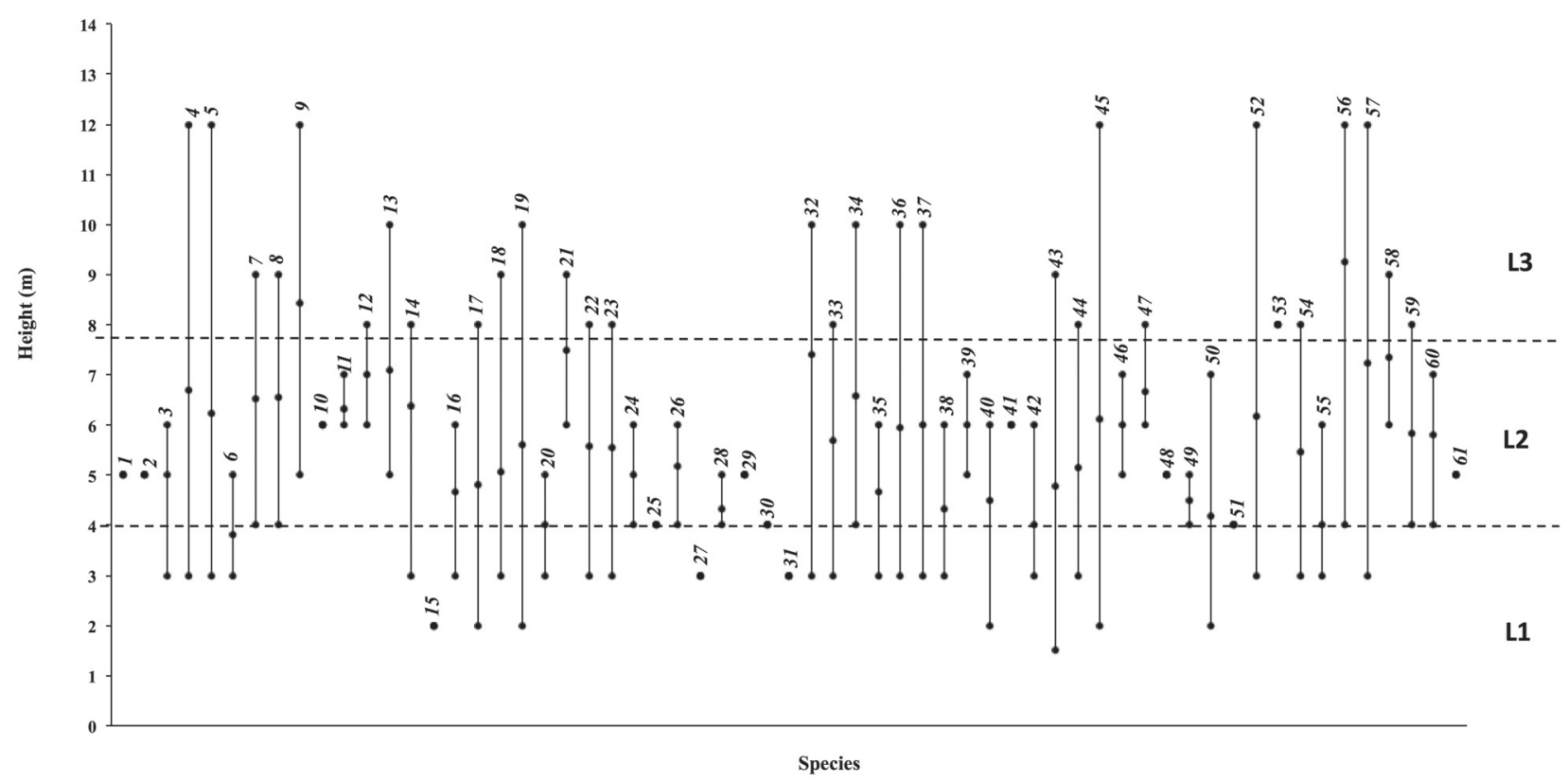

Figure 1. Distribution of the frequency of individuals, by height $(\mathrm{m})$, in the plots in the tree community of an area of cerradão in the Private Nature Reserve operated by the Federal University of Mato Grosso do Sul, in the city of Campo Grande, Brazil. Lower layer (L1: 0-4.0 m), middle layer (L2: 4.01-7.88 m), and upper layer (L3: 7.89-12 m) identified by horizontal lines.

1 L. dasycarpum; 2 A. klotzkiana; 3 A. brasiliensis; 4 A. peregrina; 5 A. cuyabensis; 6 A. coriaceae; 7 A. crassiflora; 8 A. fraxinifolium; 9 B. virgilioides; 10 B. tomentosa; 11 B. coccolobifolia; 12 B.verbasifolia; 13 C. minor; 14 C. brasiliense; 15 C. sylvestris; 16 C. marginatum; 17 C. suberosus; 18 C. langsdorffii; 19 C. americana; 20 D. mollis; 21 D. alata; 22 D. aurantiaca; 23 E. pubescens; 24 E. anguifugum; 25 E. deciduum; 26 E. suberosum; 27 E. tortuosum; 28 E. aurata; 29 E. egensis; 30 G. opposita.; 31 H. hebeclada; 32 H. stigonocarpa; 33 K. coriacea; 34 L. pacari; 35 L. humilis; 36 L. paniculata; 37 M. guianensis; 38 M. albicans; 39 M. urundeuva; 40 M. guianensis; 41 O. minarum; 42 P. rotundifolia; 43 Q. grandiflora; 44 Q. multiflora; 45 Q. parviflora; 46 R. guianensis; 47 R. montana; 48 R. induta; 49 R. viburnoides; 50 S. convallariodora; 51 S. morototoni; 52 S. obovatum; 53 S. ferrugineus; 54 Tab. aurea; 55 H. ochraceus; 56 T. aurea; 57 T. argentea; 58 T. pallida; 59 V. thyrsoidea; 60 X. aromatica; 61 Z. hasslerianum. 
Marcelo Leandro Bueno, Danilo Rafael Mesquita Neves, Anderson Fernandes Souza, Elio Oliveira Junior, Geraldo Alves Damasceno Junior, Vanessa Pontara, Valdemir Antônio Laura and James Alexander Ratter

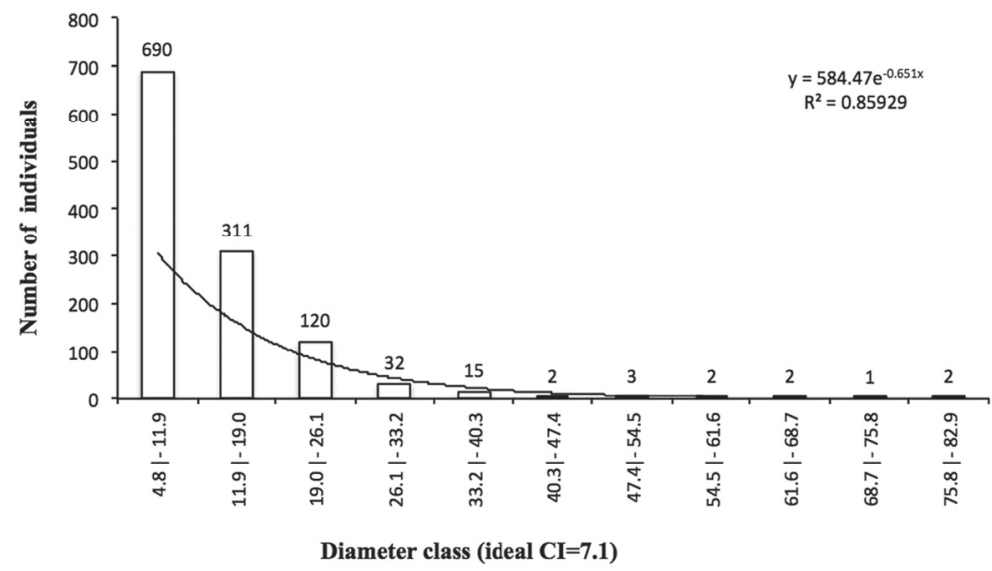

Figure 2. Distribution of the number of individuals by diameter class, with an ideal class interval (CI) of $7.1 \mathrm{~cm}$, in plots within the tree community of an area of cerradão in the Private Nature Reserve operated by the Federal University of Mato Grosso do Sul, in the city of Campo Grande, Brazil.

Table 2. Phytosociological parameters of the species recorded for the cerradão of the Private Nature Reserve operated by the Federal University of Mato Grosso do Sul, in the city of Campo Grande, Brazil.

\begin{tabular}{|c|c|c|c|c|c|c|}
\hline Scientific name & $\mathbf{N}$ & RD & RF & RDo & CV\% & IV\% \\
\hline Qualea parviflora & 291 & 24.66 & 4.17 & 24.78 & 24.72 & 17.87 \\
\hline Curatella americana & 92 & 7.8 & 3.75 & 13.48 & 10.64 & 8.34 \\
\hline Qualea grandiflora & 127 & 10.76 & 4.17 & 7.93 & 9.35 & 7.62 \\
\hline Terminalia argentea & 112 & 9.49 & 4.17 & 8.63 & 9.06 & 7.43 \\
\hline Anadenanthera peregrina var. falcata & 29 & 2.46 & 2.5 & 9.27 & 5.86 & 4.74 \\
\hline Astronium fraxinifolium & 51 & 4.32 & 4.17 & 2.23 & 3.28 & 3.57 \\
\hline Salvertia convallariodora & 24 & 2.03 & 4.17 & 1.49 & 1.76 & 2.56 \\
\hline Annona crassiflora & 21 & 1.78 & 2.92 & 2.75 & 2.27 & 2.48 \\
\hline Callisthene minor & 37 & 3.14 & 0.83 & 2.99 & 3.07 & 2.32 \\
\hline Tabebuia aurea & 21 & 1.78 & 3.75 & 1 & 1.39 & 2.18 \\
\hline Vochysia thyrsoidea & 17 & 1.44 & 2.5 & 1.6 & 1.52 & 1.85 \\
\hline Diptychandra aurantiaca & 34 & 2.88 & 0.83 & 1.6 & 2.24 & 1.77 \\
\hline Xylopia aromatica & 32 & 2.71 & 1.67 & 0.78 & 1.74 & 1.72 \\
\hline Bowdichia virgilioides & 14 & 1.19 & 2.08 & 1.9 & 1.54 & 1.72 \\
\hline Matayba guianensis & 22 & 1.86 & 2.5 & 0.63 & 1.25 & 1.67 \\
\hline Stryphnodendron rotundifolium & 12 & 1.02 & 2.92 & 0.9 & 0.96 & 1.61 \\
\hline Andira cuyabensis & 9 & 0.76 & 3.33 & 0.6 & 0.68 & 1.56 \\
\hline Connarus suberosus & 17 & 1.44 & 2.5 & 0.66 & 1.05 & 1.53 \\
\hline Tachigali aurea & 12 & 1.02 & 1.67 & 1.86 & 1.44 & 1.52 \\
\hline Lafoensia pacari & 16 & 1.36 & 1.67 & 1.49 & 1.43 & 1.51 \\
\hline Luehea paniculata & 19 & 1.61 & 2.08 & 0.58 & 1.1 & 1.42 \\
\hline Eriotheca pubescens & 9 & 0.76 & 2.92 & 0.55 & 0.66 & 1.41 \\
\hline
\end{tabular}


Table 2. Continuation

\begin{tabular}{|c|c|c|c|c|c|c|}
\hline Scientific name & $\mathbf{N}$ & RD & $\mathbf{R F}$ & RDo & CV\% & IV\% \\
\hline Hymenaea stigonocarpa & 5 & 0.42 & 0.83 & 2.94 & 1.68 & 1.4 \\
\hline Kielmeyera coriacea & 16 & 1.36 & 1.67 & 1.01 & 1.18 & 1.34 \\
\hline Copaifera langsdorffii & 17 & 1.44 & 0.83 & 1.47 & 1.46 & 1.25 \\
\hline Qualea multiflora & 13 & 1.1 & 2.08 & 0.46 & 0.78 & 1.21 \\
\hline Caryocar brasiliense & 8 & 0.68 & 2.08 & 0.83 & 0.76 & 1.2 \\
\hline Licania humilis & 6 & 0.51 & 2.5 & 0.29 & 0.4 & 1.1 \\
\hline Miconia albicans & 6 & 0.51 & 2.08 & 0.42 & 0.47 & 1.0 \\
\hline Myrcia guianensis & 8 & 0.68 & 2.08 & 0.22 & 0.45 & 0.99 \\
\hline Erythroxylum suberosum & 6 & 0.51 & 1.67 & 0.64 & 0.57 & 0.94 \\
\hline Roupala montana & 6 & 0.51 & 1.25 & 0.4 & 0.46 & 0.72 \\
\hline Piptocarpha rotundifolia & 10 & 0.85 & 0.83 & 0.33 & 0.59 & 0.67 \\
\hline Dipteryx alata & 4 & 0.34 & 1.25 & 0.25 & 0.3 & 0.61 \\
\hline Annona coriacea & 5 & 0.42 & 1.25 & 0.09 & 0.25 & 0.59 \\
\hline Rapanea guianensis & 5 & 0.42 & 1.25 & 0.08 & 0.25 & 0.59 \\
\hline Myracrodruon urundeuva & 4 & 0.34 & 1.25 & 0.06 & 0.2 & 0.55 \\
\hline Eugenia aurata & 3 & 0.25 & 1.25 & 0.08 & 0.17 & 0.53 \\
\hline Chrysophyllum marginatum & 3 & 0.25 & 1.25 & 0.06 & 0.16 & 0.52 \\
\hline Handroanthus ochraceus & 3 & 0.25 & 1.25 & 0.05 & 0.15 & 0.52 \\
\hline Erythroxylum tortuosum & 3 & 0.25 & 1.25 & 0.04 & 0.15 & 0.52 \\
\hline Rudgea viburnoides & 2 & 0.17 & 0.83 & 0.44 & 0.31 & 0.48 \\
\hline Tapirira guianensis & 3 & 0.25 & 0.83 & 0.31 & 0.28 & 0.46 \\
\hline Styrax ferrugineus & 1 & 0.08 & 0.42 & 0.76 & 0.42 & 0.42 \\
\hline Byrsonima coccolobifolia & 3 & 0.25 & 0.83 & 0.15 & 0.2 & 0.41 \\
\hline Dimorphandra mollis & 3 & 0.25 & 0.83 & 0.11 & 0.18 & 0.4 \\
\hline Agonandra brasiliensis & 3 & 0.25 & 0.83 & 0.05 & 0.15 & 0.38 \\
\hline Erythroxylum anguifugum & 2 & 0.17 & 0.83 & 0.09 & 0.13 & 0.36 \\
\hline Byrsonima verbascifolia & 2 & 0.17 & 0.42 & 0.33 & 0.25 & 0.3 \\
\hline Eugenia egensis & 1 & 0.08 & 0.42 & 0.07 & 0.08 & 0.19 \\
\hline Rourea induta & 1 & 0.08 & 0.42 & 0.05 & 0.07 & 0.18 \\
\hline Hirtella hebeclada & 1 & 0.08 & 0.42 & 0.03 & 0.06 & 0.18 \\
\hline Buchenavia tomentosa & 1 & 0.08 & 0.42 & 0.03 & 0.06 & 0.18 \\
\hline Zanthoxylum rigidum & 1 & 0.08 & 0.42 & 0.01 & 0.05 & 0.17 \\
\hline Aegiphila verticilata & 1 & 0.08 & 0.42 & 0.01 & 0.05 & 0.17 \\
\hline Casearia sylvestris & 1 & 0.08 & 0.42 & 0.02 & 0.05 & 0.17 \\
\hline Erythroxylum deciduum & 1 & 0.08 & 0.42 & 0.01 & 0.05 & 0.17 \\
\hline Guapira opposita & 1 & 0.08 & 0.42 & 0.02 & 0.05 & 0.17 \\
\hline Leptolobium dasycarpum & 1 & 0.08 & 0.42 & 0.02 & 0.05 & 0.17 \\
\hline
\end{tabular}


Table 2. Continuation

\begin{tabular}{lcccccc}
\hline Scientific name & N & RD & RF & RDo & CV\% & IV\% \\
\hline Schefflera morototoni & 1 & 0.08 & 0.42 & 0.02 & 0.05 & 0.17 \\
Ocotea minarum & 1 & 0.08 & 0.42 & 0.02 & 0.05 & 0.17 \\
\hline Total & 1180 & 100 & 100 & 100 & 100 & 100 \\
\hline
\end{tabular}

$\mathrm{N}$ - number of individuals; RD - relative density; RF - relative frequency; RDo - relative dominance; CV\% - cover value (proportional); IV\% - importance value (proportional).

frequency $(78 \%)$ in 376 areas within the cerrado biome. The most common species was Q. grandiflora, which has a wide distribution in the cerrado, occurring in $85 \%$ of the areas listed by those same authors (Ratter et al. 1996; 2003).

Some of the species recorded at our study site also occur in semi-deciduous forests, although with different IVs (Araújo \& Haridasan 1997; Araújo et al. 1997): Matayba guianensis, Rudgea viburnoides (Cham.) Benth., Tapirira guianensis Aubl., Copaifera langsdorffii Desf., Casearia sylvestris Sw., and Guapira opposita (Vell.) Reitz. Oliveira-Filho \& Ratter (1995) conducted a study of the forest formations of central Brazil and demonstrated the high exchange of species between the cerradão and other vegetation types. It is evident that the flora of the cerradão has an intermediate nature, with various aspects of savanna, forest and generalist species and therefore no indication of exclusive species.

Some species sampled in this study require additional comments. Astronium fraxinifolium Schott (with 51 individuals, IV\% 4.74) is a common species in deciduous forests and was classified as slightly mesotrophic by Ratter et al. (2011); Terminalia argentea Mart. (112 individuals, IV\% 7.62) belongs to the same category. In contrast, Luehea paniculata (19 individuals, IV\% 1.42) was classified as strongly mesotrophic by those same authors, as was Dipteryx alata Vog. (4 individuals, IV\% 0.61); whereas Myracrodruon urundeuva Allemão, frequently referred as the archetype calcicolous species, had 4 individuals and an IV\% of 0.55 . The occurrence of Astronium fraxinifolium and Terminalia argentea, which have a weak preference for mesotrophic soils, is not surprising; however, the other species are certainly unexpected. These anomalies have been recorded in other studies (Ratter, personal communication; Araújo et al. 2011; Neri et al. 2012), and it has been suggested that they occur on mesotrophic soils within dystrophic landscapes.

\section{Edaphic factors}

Also in the state of Mato Grosso do Sul, Ratter et al. (2003) found a higher frequency of cerrado areas on mesotrophic soils: 20 of the 33 areas analyzed. However, considering base saturation as an indicator of soil fertility, base saturation values $<50 \%$ being indicative of dystrophic soil (Embrapa 2006), the soil at our study site was dystrophic (base saturation, 9-29\%). Aluminum saturation was 27-73\%, representing the proportion of aluminum in relation to

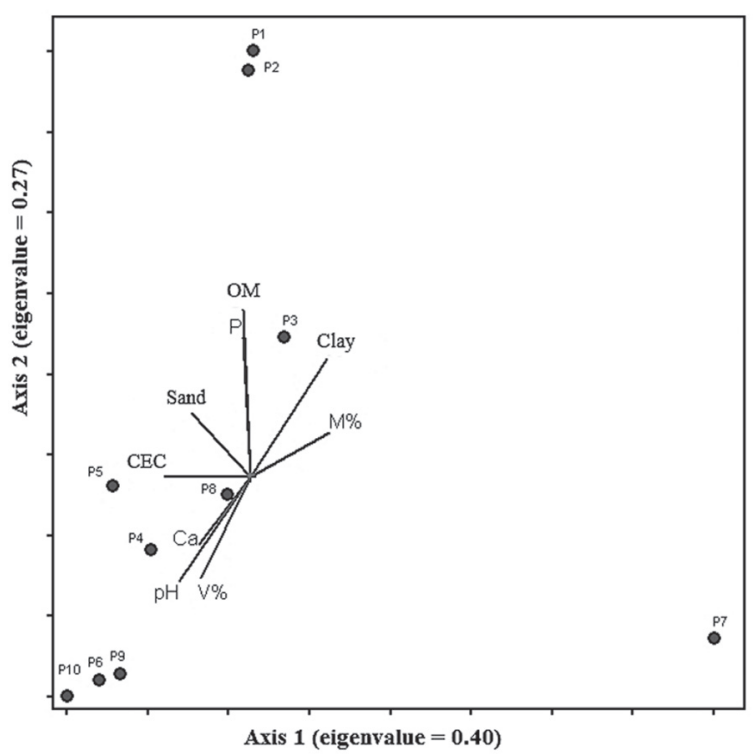

Figure 3. Canonical correspondence analysis of sampled plots and edaphic variables in the cerradão of the Private Nature Reserve operated by the Federal University of Mato Grosso do Sul, in the city of Campo Grande, Brazil. $\mathrm{OM}$ - organic matter; CEC -cation exchange capacity.

the sum of $\mathrm{Ca}^{2+}, \mathrm{Mg}^{2+}, \mathrm{K}^{+}, \mathrm{Na}^{+}$, and $\mathrm{Al}^{3}$ in the soil; higher aluminum saturation values indicate soils with less fertility and higher aluminum concentration.

In the CCA, the eigenvalues obtained for axes 1 and 2 were low ( 0.40 and 0.27 ; respectively), which implies low floristic turnover between the plots (ter Braak 1995). Axes 1 and 2, respectively, explained $26.8 \%$ and $18.1 \%$ of the variance $(P<0.001$ for both), collectively accounting for $44.9 \%$ of the accumulated variance (Fig. 3). A considerable proportion (65.1\%) was not explained by the predictors or was stochastic in nature (Hubbell, 2001). However, this high level of noise is common in vegetation studies and does not compromise the species-environment relationship (ter Braak 1988). In the diagram of the CCA (Fig. 3), axis 1 was efficient in segregating plots 3 and 7. Those plots had lower CEC values and higher aluminum saturation (Tab. 3), which might explain the differentiation in species composition. The fact that Qualea parviflora and Qualea grandiflora were the most abundant species in these plots corroborates those results, because species of the family Vochysiaceae are classified as 
Table 3. Chemical and physical characteristics of the soil (depth, $0-20 \mathrm{~cm}$ ) of the 10 plots evaluated in the cerradão of the Private Nature Reserve operated by the Federal University of Mato Grosso do Sul, in the city of Campo Grande, Brazil.

\begin{tabular}{|c|c|c|c|c|c|c|c|c|c|c|c|c|c|c|c|}
\hline \multirow[b]{2}{*}{ Plot } & $\mathrm{pH}$ & $\mathrm{P}$ & $\mathrm{K}^{+}$ & $\mathrm{Ca}^{2+}$ & $\mathrm{Mg}^{2+}$ & $\mathrm{Al}^{3+}$ & $\mathrm{H}^{+}+\mathrm{Al}^{3+}$ & SB & CEC & $\mathrm{OM}$ & $\mathrm{m}$ & V & Clay & Silt & Sand \\
\hline & $\mathrm{H}_{2} \mathrm{O}$ & \multicolumn{2}{|c|}{$\mathrm{mg} / \mathrm{dm}^{3}$} & \multicolumn{6}{|c|}{$\mathrm{cmol}_{\mathrm{c}} / \mathrm{dm}^{3}$} & $\begin{array}{l}\mathrm{mg} / \\
\mathrm{dm}^{3}\end{array}$ & \multicolumn{2}{|c|}{$\%$} & \multicolumn{3}{|c|}{$\mathrm{g} / \mathrm{kg}$} \\
\hline 1 & 5.25 & 2 & 72 & 0.7 & 1.6 & 0.9 & 8.25 & 2.5 & 10.7 & 49.2 & 27 & 23 & 525 & 244 & 231 \\
\hline 2 & 5.09 & 2 & 58 & 0.5 & 1.3 & 1.8 & 9.74 & 1.9 & 11.7 & 39.1 & 48 & 17 & 544 & 270 & 186 \\
\hline 3 & 5.11 & 1 & 58 & 0.3 & 0.3 & 2 & 7.76 & 0.7 & 8.5 & 35.3 & 73 & 9 & 504 & 298 & 198 \\
\hline 4 & 5.22 & 1 & 58 & 0.2 & 1.4 & 1.4 & 7.43 & 1.7 & 9.2 & 32.4 & 44 & 19 & 540 & 274 & 186 \\
\hline 5 & 5.24 & 1 & 58 & 0.3 & 1.3 & 1.5 & 8.09 & 1.7 & 9.8 & 33.9 & 46 & 18 & 522 & 304 & 174 \\
\hline 6 & 5.44 & 1 & 87 & 0.6 & 2.3 & 1.5 & 8.91 & 3.1 & 12 & 33.8 & 32 & 26 & 472 & 321 & 207 \\
\hline 7 & 5.18 & 1 & 58 & 0.5 & 1.2 & 2 & 7.43 & 1.8 & 9.3 & 33.1 & 52 & 20 & 526 & 300 & 174 \\
\hline 8 & 5.26 & 2 & 87 & 0.6 & 1.2 & 1.5 & 8.25 & 2.0 & 10.3 & 34.9 & 43 & 20 & 506 & 292 & 202 \\
\hline 9 & 5.17 & 1 & 87 & 0.9 & 1.4 & 1.6 & 8.91 & 2.5 & 11.4 & 33.2 & 39 & 22 & 470 & 315 & 215 \\
\hline 10 & 5.28 & 1 & 79 & 1.6 & 1.4 & 1.4 & 7.92 & 3.2 & 11.1 & 34.6 & 30 & 29 & 479 & 346 & 175 \\
\hline
\end{tabular}

$\mathrm{SB}$ - sum of bases; CEC - cation exchange capacity; OM - organic matter; $\mathrm{m}$ - aluminum saturation; $\mathrm{V}$ - base saturation.

tolerant to and obligate accumulators of aluminum (Haridasan 2000). Axis 2 was efficient in segregating plots 6, 9 and 10 , with more fertile soils, higher values of CEC and lower aluminum saturation. These three plots had species that co-occur in areas of cerradão with mesotrophic soils (Ratter et al. 1977), such as Terminalia argentea, Luehea paniculata and Astronium fraxinifolium. This demonstrates that soil fertility is a determinant of species composition in the cerrado.

In general, the soil of the plots had a clay texture (Tab. 3). According to Marimon-Junior \& Haridasan (2005), clay soils under cerradão vegetation have a higher water-retention capacity and are therefore more capable to support the processes of biomass synthesis and maintain higher fertility, because water availability regulates the dynamics of nutrients in the soil, and consequently, their absorption by the plants. Ribeiro (1983), comparing cerradão and cerrado típico, found differences in the physical characteristics of the soil: that of the cerradão had higher porosity and higher water-retention capacity. This water regime, which is more favorable to the community than is that of the cerrado típico, might be an important factor restricting the distribution of cerradão. It should be noted that many soils in Brazil, although classified as clay soils, behave similarly to sandy soils in terms of CEC. This is explained by the fact that these clays are, predominantly, of low activity (kaolinite, iron and aluminum sesquioxides, etc.), and most latosols under cerrado are part of this category (Lopes \& Guilherme 1992).

\section{Conclusion}

Our findings, together with those of the other studies discussed, support the hypothesis of our study, that there is a relationship between edaphic factors and species dis- tribution in the cerradão. The clay soils favored the predominance of tree species, whereas the dystrophic soils, with considerable variation in aluminum saturation, influenced the floristic turnover between the plots.

Although the study site is classified as an area of dystrophic cerradão, we recorded species that are characteristic of mesotrophic soils and deciduous forests. The presence of those species might be related to the existence of areas with mesotrophic soils within a dystrophic landscape, as has previously been suggested.

\section{Acknowledgments}

We thank the UFMS for authorizing the collection within the RPPN. We are also grateful to professors Arnildo Pott and Ângela Lúcia Bagnatori Sartori (curator of the CGMS Herbarium), who assisted in the identification of the botanical material, as well as to Carlos R. Lehn and the two anonymous reviewers, for their essential suggestions to improve the manuscript.

\section{References}

Alencar, A.L.; da Silva, M.A.P. \& Barros, L.M. 2007. Florística e Fitossociologia de uma Área de Cerradão na Chapada do Araripe - Crato - CE. Revista Brasileira de Biociências 5: 18-20.

Andrade, L.A.Z.; Felfili, J.M. \& Violatti, L. 2002. Fitossociologia de uma área de cerrado denso na Recor-IBGE, Brasília-DF. Acta Botanica Brasilica 16: 225-240.

APG III. 2009. An update of the Angiosperm Phylogeny Group classification for the orders and families of flowering plants. Botanical Journal of the Linnaean Society 161: 105-202.

Araújo, G.M. \& Haridasan, M. 1997. Estrutura fitossociológica de duas matas mesófilas semidecíduas, em Uberlândia, Triângulo Mineiro. Naturalia 22: 115-129. 
Araújo, G.M.; Guimarães, A.J.M. \& Nakajima, J.N. 1997. Fitossociologia de um remanescente de mata mesófila semidecídua urbana, Bosque Jonh Kennedy, Araguari, MG, Brasil. Revista Brasileira de Botânica 20: 67-77.

Araújo, G.M.; Nascimento, A.R.T.; Lopes, S.F.; Rodrigues, R.F. \& Ratter, J.A. 2011. Structure and floristics of the arboreal component of a dystrophic cerradão and comparison with other cerrados in Central Brazil. Edinburgh Journal of Botany 68: 401-418.

Assis, A.C.C.; Coelho, R. M.; Pinheiro, E. da S. \& Durigan, G. 2011. Water availability determines physiognomic gradiente in an area of lowfertility soils under Cerrado vegetation. Plant Ecology 212:1135-1147.

Batalha, M.A. \& Mantovani, W. 2001. Floristic composition of the cerrado in the Pé-de-Gigante Reserve (Santa Rita do Passa Quatro, southeastern Brazil). Acta Botanica Brasilica 15: 289-304.

Brower, J.E. \& Zar, J.H. 1984. Field \& laboratory methods for general ecology. Boston, W.C. Brown Publishers.

Cientec. 2007. Mata Nativa 2: sistema para análise fitossociológica e elaboração de planos de manejo de florestas nativas. Viçosa, Cientec - consultoria e desenvolvimento de sistemas.

Costa, A.A. \& Araújo, G.M. 2001. Comparação da vegetação arbórea de cerradão e de cerrado na reserva do Panga, Uberlândia, Minas Gerais. Acta Botanica Brasilica 15: 63-72.

Embrapa - CNPGC. 1985. Boletim Agrometeorológico. Campo Grande, Editora Embrapa.

Embrapa. 2006. Centro Nacional e Pesquisa em Solos. Sistema Brasileiro de Classificação de Solos. Brasília: Embrapa-SPI; Rio de Janeiro, Embrapa-Solos.

Embrapa. 1998. Centro Nacional de Pesquisa de Solos. Manual de análise química e física do solo. Rio de Janeiro, Embrapa Solos.

Felfili, J.M. \& Silva Júnior, M.C. 1992. Floristic composition, phytosociology and comparison of cerrado and gallery forests at Fazenda Água Limpa, Federal District, Brazil. Pp: 393-407. In: Furley, P.A.; Proctor, J. \& Ratter, J.A. (Eds.). Nature and Dynamics of Forest: savanna boundaries London, Chapman \& Hall.

Furley P.A. \& Ratter, J.A. 1988. Soil resources and plant communities of the central Brazililian cerrado and their development. Journal of Biogeography 15: 97-108.

Gomes, B.Z.; Martins, F.R. \& Tamashiro, J.Y. 2004. Estrutura do cerradão e da transição entre cerradão e floresta paludícola num fragmento da International Paper do Brasil Ltda., em Brotas, SP. Revista Brasileira de Botânica 27: 249-262.

Guimarães, A.J.M.; Corrêa, G.F. \& Araújo, G.M. 2001. Características da vegetação e do solo em duas comunidades vegetais contíguas no Triângulo Mineiro. Boletim do Herbário Ezechias Paulo Heringer 7: 113-127.

Haridasan, M. 1992. Observations on soils, foliar nutrient concentration snd floristic composition of cerrado sensu stricto and cerradão communities in central Brazil. Pp: 171-184. In: Furley, P. A.; Proctor, J. \& Ratter, J. A. (Eds.). Nature and Dynamics of Forest: savanna boundaries London, Chapman \& Hall.

Haridasan, M. 2000. Nutrição mineral de plantas nativas do cerrado. Revista Brasileira de Fisiologia Vegetal 12: 54-64.

Hubbell, S.P. 2001. The Unified Neutral Theory of Biodiversity and Biogeography. Princeton, Princeton University Press.

Köppen, W. 1948. Climatologia: con un estudio de los climas de la tierra. México. Fondo de Cultura Econômica.

Lopes, A.S. \& Guilherme, L.R.G. 1992. Interpretação de análise de solo, conceitos e aplicações. In: ANDA (Associação Nacional para Difusão de Adubos). São Paulo, Boletim técnico n².

Marimon-Junior, B.H. \& Haridasan, M. 2005. Comparação da vegetação arbórea e características edáficas de um cerradão e um cerrado sensu stricto em áreas adjacentes sobre solo distrófico no leste de Mato Grosso, Brasil. Acta Botanica Brasilica 19: 913-926.

Mccune, B. \& M. J. Mefford. 2006. PC-ORD. Multivariate Analysis of Ecological Data. Version 5.10 MjM Software, Oregon, Gleneden Beach.

Mueller-Dombois, D. \& Ellenberg, H. 1974. Aims and methods of vegetation ecology. New York, John Wiley \& Sons.

Neri, A.V.; Schaefer, C.E.G.R.; Silva, A.F.; Souza, A.L.; Ferreira Junior, W.F. \& Meira Neto, J.A.A. 2012. The influence of soils on the floristic composition and community structure of an area of Brazilian cerrado vegetation. Edinbrugh Journal of Botany 69: 1-27.

Neri, A.V.; Schaefer, C.E.G.R.; Souza, A.L.; Ferreira-Junior, W.G. \& MeiraNeto, J.A.A. 2013. Pedology and plant physiognomies in the cerrado, Brazil. Anais da Academia Brasileira de Ciências 85: 87-102.

Oliveira-Filho, A.T. \& Ratter, J.A. 1995. A study of the origin of Central Brazilian forests by the analysis of plant species distribution patterns. Edinburgh Journal of Botany 52: 141-194.

Paula, A.; Silva, A.F.; Marco Júnior, P.; Santos, F.A.M. \& Souza, A.L. 2004 Sucessão ecológica da vegetação arbórea em uma floresta estacional semidecidual, Viçosa, MG, Brasil. Acta Botanica Brasilica 18: 407-423.

Pinheiro, E.S; Durigan, G. 2012. Diferenças Florísticas e Estruturais entre Fitofisionomias do Cerrado em Assis, SP, Brasil. Revista Árvore, Viçosa-MG. 36: 181-193.

Ratter, J.A. 1971. Some notes on two types of cerradão occurring in north eastern Mato Grosso. Pp: 100-102. In: In: Ferri, M. G. (Coord.). III Simpósio sobre o cerrado. Universidade de São Paulo.

Ratter, J.A. 1986. Notas sobre a vegetação da Fazenda Água Limpa (Brasília, DF, Brazil). Brasília, Editora UnB (Textos Universitários n. 3).

Ratter, J.A.; Richard, P.W.; Argent, G.T. \& Gifford, D.R. 1973. Observations on the vegetation of north eastern Mato Grosso. I. The woody vegetation types of the Xavantina-Cachimbo Philosophical Transaction for the Royal Society of London, Series Biological Sciences 226: 44-492.

Ratter, J.A.; Askew, G.P.; Montgomery, R.F. \& Gifford, D.R. 1977. Observações adicionais sobre o cerradão de solos mesotróficos no Brasil central. Pp: 303-316. In: Ferri, M.G. (Ed.). IV Simpósio sobre o Cerrado: Bases para a Utilização Agropecuária. EDUSP, São Paulo.

Ratter, J.A.; Bridgewater, S; Atkinson, R. \& Ribeiro, J.F. 1996. Analysis of the floristic composition of the Brazilian Cerrado vegetation II: comparison of the woody vegetation of 98 areas. Edinburgh Journal of Botany 53: 153-180.

Ratter, J.A.; Ribeiro, J.F. \& Bridgewater, S. 1997. The brazilian cerrado vegetation and threats to its biodiversity. Annals of Botany 80: 223-230.

Ratter, J.A.; Bridgewater, S. \& Ribeiro, J.F. 2003. Analysis of the floristic composition of the Brazilian cerrado vegetation III: comparison of the woody vegetation of 376 areas. Edinburgh Journal of Botany 60: $57-109$.

Ratter, J.A.; Bridgewater, S. \& Ribeiro, F. 2006. Biodiversity patterns of the woody vegetation of the Brazilian Cerrado. Pp.31-65. In: Pennington, R.T.; Lewis G.P. \& Ratter, J.A. (Eds.). Neotropical savannas and seasonally dry forests: plant diversity, biogeography and conservation. Taylor \& Francis, London.

Ratter, J.A.; Bridgewater, S., Ribeiro, J.F., Fonseca-Filho, J., Rodrigues da Silva, M., Milliken, W., Pott, A., Oliveira-Filho, A.T., Durigan, G. \& Pennington, R.T. 2011. Analysis of the floristic composition of the Brazilian Cerrado vegetation IV: revision of the comparison of the woody vegetation of 367 areas and presentation of a revised data-base of 367 areas. Disponível em http://www.cerrado.rbge.org. uk. (Acesso em 20/03/2012).

Reis, A.; Zambonin, R.M. \& Nakazono, E. M. 1999. Recuperação de áreas florestais degradadas utilizando a sucessão e as interações planta-animal. Série Cadernos da Biosfera 14. São Paulo, Conselho Nacional da Reserva da Biosfera da Mata Atlântica.

Ribeiro, J.F. \& Walter, B.M.T. 2008. As principais fitofisionomias do Bioma Cerrado. Pp: 151-212. In: Sano, S.M.; Almeida, S.P. \& Ribeiro, J.F. (Eds.). Cerrado: Ecologia e Flora. Brasília, Embrapa Cerrados.

Ribeiro, J.F. 1983. Comparação da concentração de nutrientes na vegetação arbórea e nos solos de um Cerrado e um Cerradão no Distrito Federal, Brasil. Dissertação de Mestrado, Universidade de Brasília, Brasília.

Ribeiro, J.F.; Silva, J.C.S. \& Batmanian, G.J. 1985. Fitossociologia de tipos fisionômicos de cerrado em Planaltina, DF. Revista Brasileira de Botânica 8: 131-142.

Salis, S.M.; Assis, M.A.; Crispim, S.M.A. \& Casagrande, J.C. 2006. Distribuição e abundância de espécies arbóreas em cerradões no Pantanal, Estado do Mato Grosso do Sul, Brasil. Revista Brasileira de Botânica 29: $339-352$ 
Silva Júnior, M.C. \& Silva, A.F. 1988. Distribuição dos diâmetros dos troncos das espécies mais importantes do cerrado na estação florestal de experimentação de Paraopeba (EFLEX)- MG. Acta Botanica Brasilica 2: 107-126.

Silva, D.W. \& Soares, J.J. 1999. Estrutura etária das principais populações arbóreas em uma área de cerradão na Fazenda Canchim, São Carlos, SP. Revista de Ciências Exatas e Naturais 1: 57-65.

Silva, H.G.; Figueiredo, N. \& Andrade, G.V.A. 2008. Estrutura de um Cerradão no nordeste do Maranhão foi avaliada visando contribuir para a caracterização da heterogeneidade da vegetação no Estado. Revista Árvore, Viçosa-MG. 32: 921-930.

Souza, P. B.; Alves, J. A.; Silva, A. F. \& Souza, A. L. 2008. Composição Florística da Vegetação Arbórea de um Remanescente de Cerradão, Paraopeba, MG. Revista Árvore, Viçosa-MG. 32: 781-790.
Spiegel, M.P. 1976. Estatística. São Paulo, McGraw-Hill do Brasil. ter Braak, C.J.F. \& Prentice, I. C. 1988. A theory of Gradient Analysis. Advances in Ecological Research 18: 271-317.

ter Braak, C.J.F. 1995. Ordination. Pp: 91-173. In: Jongman, R.H.G.; ter Braak, C.J.F.; \& van Tongeren, O.F.R. (Eds.). Data analysis in community and landscape ecology. Cambrigde, Cambrigde University Press. Toppa, R.H. 2004. Estrutura e diversidade florística das diferentes fisionomias de cerrado e suas correlações com o solo na Estação Ecológica de Jataí, Luiz Antônio, SP. Tese (Programa de Pós-Graduação em Ecologia e Recursos Naturais). Universidade Federal de São Carlos, São Carlos.

Zar, J.H. 1999. Biostatistical analysis. New Jersey, Prentice Hall. 